\title{
Julmaa optimismia
}

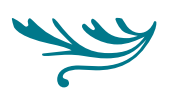

Ruotsalaisen Johan Klingin elokuvassa ”Darling” ABB:lta irtisanottu, kuusikymppinen, vaimonsa jättämä insinööri on positiivinen mies. Hän on avoin ja sosiaalinen ja valmis oppimaan aina uutta. Myyntityö sujuu koeajalla hyvin, mutta ruumillinen olemus - vatsakkuus, etukumara ryhti, roikkuvat posket - vahingoittaa firman imagoa. Bernard saa lähteä myyjän hommista, mutta hakee sinnikkäästi uutta pestiä. McDonaldsille hän kelpaa, kunhan vaihtaa pomonpaidan ylleen, jotteivät asiakkaat vaivaantuisi siitä, että väärän ikäiset ihmiset palvelevat heitä.

Suomalaisessa yliopistossa tutkijan määräaikaisia työsuhteita ei enää uusita. Osaamisloikkaa tavoitellaan vaihtamalla henkilökunta maailmanluokan 
lahjakkuuksiin. Ylimenokaudella jää kuitenkin irtokursseja vaille opettajaa. Tutkijalle tarjotaan mahdollisuutta säilyttää yliopiston affiliaatio nimensä perässä hieman pidempään tarkastamalla irtisanotun kollegan entistä kirjatenttiä pientä tuntikorvausta vastaan. Tutkija miettii, olivatko humboldtilaiset ihanteet vain idealismia, eikö yhteiskunta tarvitsekaan lukeneistoaan, ja olisiko hän sittenkin vain vanheneva nainen.

\section{OPTIMISTISIA UNELMIA}

Masentumistaipumuksestakin voi oppia pois sopivilla kursseilla. Nyky-yhteiskunnassa pitää osata kierrättää sekä jätteitä että itseään.

Kuntouttavassa työtoiminnassa pitkäaikaistyöttömät valmistavat kierrätysmateriaaleista polkupyöriä, astioita, koruja, leluja ja laukkuja. He olivat joskus maalareita, hitsaajia, kokkeja ja kotiäitejä. Nyt he oppivat huovutusta, pinnoitusta ja dreijausta sekä ATK-taitoja, suomen kieltä, täsmällisyyttä ja päihteettömyyttä. Nimien ei pidä antaa hämätä. Työhönkuntoutuksen yksiköstä kuntoutuvat palkkatyöhön vain ne, jotka suostuvat siivousryhmään. Siellä he oppivat nauramaan elämälle. Korvaukseksi neljän tunnin päivittäisestä kuntoutumisesta kukin saa yhdeksän euroa, lounaan ja bussikortin - paitsi ne, joiden sosiaalityöntekijä ei näe kaikkia etuja tarpeellisiksi. Kun aikataulut talossa muuttuvat, kuntoutujat joustavat. Heillä ei ole muuta elämää, eikä muita velvoitteita kuin velvoite kuntoutua työhön. Se on julmaa optimismia jos mikä.

Yhdysvaltalaisen kirjallisuuden professorin Lauren Berlantin kehittämä julman optimismin ilmaisu sanoittaa tunnetilaa, jossa nyky-yhteiskunnan jäsenet pyristelevät tavoitellen yhä liberaaliin val- tioon yhdistettyjä mahdollisuuksia edetä elämässä ja "tulla joksikin". Vaikka neoliberaali yhteiskunta haalistaa nämä fantasiat, prekaareihin olosuhteisiin pakotetut ihmiset takertuvat optimistisin unelmiin, jotka eivät toimi käytännössä. Tällöin he ovat julmia itselleen, mutta heitä myös kehotetaan tavoittelemaan muiden määrittämiä unelmia, jolloin julmuuden aste syvenee.

\section{IHMINEN EI VAPAUDU KOULUTTAMALLA}

Jokainen työtä tekevä on alalla, joka voidaan rakennemuuttaa huomenna. Ihmisiä paikkailemalla eivät rikkinäiset työt kuitenkaan korjaannu. Vain johdon konsultointiin ja loppuunpalaneiden couchingiin syntyy lisää työpaikkoja, mikä ei riitä kaikille.

Yhteiskunta ei osaa korjata työtä. Siksi tarpeettomat kansalaiset ohjataan kuntoutukseen: re-education through labour. Työttömyysjaksojen ja aktivointitoimien temppurata on tarvittaessa elinikäinen, ja siihen kuuluu terveellisten elämäntapojen opiskelu. Opiskelu ei kuitenkaan saa johtaa liian hyviin tai huonoihin tuloksiin. Liian hyvin hoidettu kunto on epäilyttävä yhteiskunnan elätillä. Huonosti hoidettu kuntokaan ei auta ulos köyhyydestä: eläkkeelle saakka on vaikea sairastua, sillä eläkekunnon ja hautakunnon väliin jää kovin kapea rako. Siinä voi käydä niin, että joulunpyhien jälkeen ihminen ei enää saavukaan kuntoutukseen, vaan taukohuoneen pöytään ilmestyy pieni vaasi tekokukkia.

Ranskalainen emeritusfilosofi Jacques Rancière muistuttaa meitä siitä, että ihmistä ei voi vapauttaa kouluttamalla. Tasa-arvo ja emansipaatio eivät väiky jossain voimauttamiskurssien lopputuloksena, vaan ne ovat oletusarvoja, joiden pohjalta voidaan esittää 


\section{OPITAANKO NYKY-YHTEISKUNNASSA}

\section{KIERRÄTT $\ddot{A M A ̈ A N N ~ J A ̈ T T E I D E N ~ L I S A ̈ K S I ~}$}

\section{ITSE $\ddot{A} \ddot{A}$ ?}

uhkarohkeita vaatimuksia ja tehdä otsakkaita esiinmarsseja. Subjekti ei synny hallinnollisen projektin tuotteena vaan sen murtumasta. Demokraattisten esiinmarssien merkitsemä hallinto on monien säröjen ja kolhujen tila. Siloinen elinkautisoppimisen järjestelmä on jotakin ihan muuta.

Kirjoitus perustuu elokuvan ja kirjallisuuden ohella kirjoittajan ja hänen kollegoidensa kokemuksiin sekä meneillään olevaan kenttätyöhön kuntouttavassa työtoiminnassa.

Marja-Liisa Trux

FT, tutkija-opettaja

Aalto yliopiston kauppakorkeakoulu
KIRJALLISUUS

Berlant, Lauren (2011). Cruel Optimism. Durham: Duke University Press.

Biesta, Gert (2010). A New Logic of Emancipation: The Methodology of Jacques Rancière. Educational Theory, 60(1): 39-58.

Mannevuo, Mona (2012). Julman optimistista onnellisuuspolitiikkaa. Teoksessa: Kirsti Lempiäinen, Taru Leppänen ja Susanna Paasonen (toim.) Erot ja etiikka feministisessä tutkimuksessa. Turku: Utukirjat. 